\title{
AN ANALYSIS OF SLANG LANGUAGE AS SOCIAL VARIATION PRODUCED BY MEN AND WOMEN'S SPEECH IN LAMONGAN
}

\author{
Moh. Nurman \\ mohnurman1982@gmail.com \\ Pendidikan Bahasa Inggris, Fakultas Keguruan dan Ilmu Pendidikan, Universitas Islam Lamongan
}

\begin{abstract}
This research aims to describe the Slang Language as a social variation produced by men and women's speech in the age of 18-25 years old found in Lamongan. The research used ethnography research design. The subjects were three men and three women from Lamongan. to collect the data, this present study used interview and observation. The data obtained, then, were analyzed qualitatively by describing the language variation used by the men and the women's speech in Lamongan. The result shows that language variation was used by those three men and three women. Mostly, they used language in various style when they communicated to their friends. It often took place when they gather among their friends. Specific language became pride a the level of their social. Some factors that caused the men and women's speech used the language variation dealt with the environment, association, media, social status and different culture.
\end{abstract}

Keywords: Language variation, Slang, adolescence age.

\section{INTRODUCTION}

Language is the human capacity for acquiring and using complex systems of communication, and a language is any specific example of such a system. The scientific study of language is called linguistics. The system of language can be compared with another system. It means that the language is just not the words that we would like to talk, speak, communicate and information but language has a variety of meaning. So, that is why, language has the wide capacity in the world; moreover, it is the second language (Meyer, 2009:3). Because language is a system of communication, it is useful to compare it with other systems of communication. For instance, human communicates not just through language but through means such as gesture, art dress, and music.

Language has origin language or natural language which comes from a human that has been staying in a different culture. It can grow and get progress with the running of time. It produces the character of language style when communication happens among them. So that it is called natural language. According to Coulmas (1998:12), natural language has two implications: on the one hand, that one is not working with "unnatural" made-up sentences of the grammar book. On the other hand, that one is bound to try to overcome Labov's "observer's paradox" as much as possible.

Language that we use daily is in our daily life is various. The fact for the researcher, evidently that variety causes appear of obstructions in efforts to show that every language has a homogenous identity, that there is a possibility to write a complete grammar for language to benefit categorical rules, that is determined by rules what is possible and impossible in language (Ibrahim, 2009:5). The identity in language is the character that everybody has a different culture. It marks that language describes people where they stay. Language variation which happens to men and women especially adolescence is a different character which has determined the structure to deliver language as common communication and this happens not only for the voice as the sound of 
language but also body language does. It is the base instinct that gets difficult to translate or understand it. According to (Hymes, 1996:26) The generic potentially of the human faculty for language is realized differently, as to directional and as to the degree in different communities.

\section{Language Variation}

In some ways, it is surprising that language variation develops as the progress of modern era. People passed down through the generation reliably enough for parents and children to communicate each other.

There are many languages bring about the variation when it is used for communication as they have been staying in their environment. They use it for communication of social, political and economic. All languages exhibit internal variation that is each language is in one sense the sum of those varieties (Wardhaugh, 2006:25). The vocabulary and phrases people use depend on where they live, their age, education level, social status and other factors. Through interactions, they pick up new words and sayings and integrate them into speech. Teens and young adults for example, often use different words and phrases from their parents. Some of them spread through the population and slowly change the language.

Some aspects of language variation happen over time: vocabulary, sentence structure, and pronunciations. Vocabulary can change as the variation of words quickly borrowed from other languages, or as words get combined or shortened. Some words are even created by mistake. While vocabulary can change quickly, sentence structure the order of words in a sentence changes more slowly. Variation of pronunciations happens to sound. The vowel of the sound is modified by the speakers that arise in the character and style of language. Systematic change, as term suggest, affect an entire system or subsystem of the language. The change may be conditioned or unconditioned. According to (Wardhaugh, 2006:135) Languages vary in many ways. One way of characterizing certain variation is to say that speakers of a particular language sometimes speak different dialects of that language.

\section{Slang}

Language, like other forms of social activity, has to be appropriate to the speakers using it. This is why, in many communities, men and women's speech is different.

Most of Lamongan slang is created and used by males. It can find that the gender difference in use and tolerance of slang was leveling out in contemporary society and that the stereotype of males being the primary slang users was open to question. Many types of slang words including the taboo and strongly derogatory ones, those referring to sex, women, work, money, whiskey, politics, transportation, sports, and the like refer primarily to male endeavor and interest.

The majority of entries in all slang dictionaries could be labeled "primarily masculine

use". Moreover, men belong to more subgroups than do women; men create and use occupational and jargon, in business, men have acquaintances that belong to many different sub-groups. Women, on the other hand, still tend to be restricted to family and neighborhood friends. Women have very little of their own slang, the new words applied to women's clothing, hairstyles, homes, kitchen utensils and gadgets are usually created by men. Except when she accompanies her boyfriend or husband to his recreation (football, hunting, etc.), a woman seldom mingles with other groups. When women do mingle outside of their own neighborhood and family circles, they do not often talk of 
the outside world of business, politics, or other fields of general interest where new feminine names for objects, concepts, and viewpoints could evolve. Women, who do work usually replace men at men's jobs, are less involved in business life than men and have a shorter business career (often only an interim between school and marriage).

According to Boldashina (2005:21), Communication is the transmission and reception of information. It means that the elements necessary communication to take place as being: a sender, a receiver, something to transmit or communicate about, communicative intend and a medium of transmission.

the Language of communication implicates the people as the sender and receiver to interact in society to get the response from another one. People contact and share in different dialects and accents but it has the same function as language. They have the system to speak with using their character as of where they come from.

\section{Adolescence Age}

Adolescence is a time of rapid physical change along with sometimes striking alterations in mood and behavior. Adolescence is sometimes thought of as a unique phase of human development, developing organism of all mammalian species go through similar transition from dependence into independence. Indeed, human adolescences and their counterpart in other species share numerous similarities in hormonal changes, behavioral characteristics and brain transformation. (Spear, 2000). Change happens in running of time when physically body grows up from childhood to be adult. It affects the behavior and thought through the transition of the brain. Behavioral characteristics are described
Slang may be characterized as a very informal language variety that includes news and sometimes not polite words and meanings. It is often used among particular groups of people, for examples, groups of teenagers or professional groups, and is usually not used in serious speech or writing.

\section{Language as Communication}

from environment around. Even the language that they speak is modern and new. Although it is informal language. The period of adolescence is a long transition when men and women's speech do interaction one another. He/she wants to explore something new which never sees before. At about ten years old men and women's speech begin the long trek through adolescence. With its jagged and under fined path, the fascinating journey can be demanding and disorienting, invigorating and exciting. It marks the beginning of a quest for identity and the way to find meaning and a place in the world (UNICEF, 2002:1).

\section{METHOD}

Employing ethnography research design, the study investigates the use of Slang language as social variation employed by men and women in the age of 18 to 20 years old in Lamongan. The subjects were three men and three women from Lamongan. To collect the data, this present study used interview and observation. The process of interview was recorded through the video. The list of questions was proposed orally using Indonesian. the Observation was done in two areas, education and public areas. Those two areas were selected to know how the men and women's speech used language as communication. The different areas were unable to give the information of language variation that they used as communication. It was done three times in different places. The data obtained, then, 
were analyzed qualitatively by describing the language variation used by the men and women's speech in Lamongan.

\section{FINDINGS AND DISCUSSION}

The findings show that language variation used by the men and women's speech in age 18-25 years old in Lamongan. The variation was used from word to word, sentence to sentence and informal language. There were many words which become abbreviation. The collecting of words has the specific meaning and stylish. This case usually took place in group, community and peering friends. In brief, basically, language variation that they used had a specific understanding. Actually, it was difficult to understand if the men or women did not get interaction in group or community.

Table 1. Language Variation that Happens between Men and Women

1. Keles. It means that "kali". For example, biasa aja keles

2. Bingit. It means that "banget". For example, males bingit

3. Woles. it means that "slow/nyantai". For example, woles bro.

4. Masbulo. It means that "maksud loe"

5. Ciyuss. It means that "serius". For example, ah masak! Ciuss.

6. O.T.W. It means that "on the way". For example, aku lagi OTW

7. Cucok is cocok. It means suitable with the things that someone uses. For exmple, anak itu cucok banget memakai topi merah.

8. Sandalan is memakai sandal it means someone who wears sandal. For example, aku nggak sandalan.

9. B.S.W. It means that "biasa wae"

10. Керо. It means that someone who wants to know indeed.

The Language was used by the men and women was various. It describes that association both men and women's speech were stylish in determining words. The combination words, non-standard words, and informal language were language communication which became

the habit of them. It happened in their daily activity.

Table 2. Common Language Variation between men and women

\begin{tabular}{|c|c|c|}
\hline No. & Languages' men & Languages' women \\
\hline 1. & $\begin{array}{l}\text { Kimcil is calling } \\
\text { name for the } \\
\text { naughty women who } \\
\text { is still blue or } \\
\text { underage. It is the } \\
\text { popular name for } \\
\text { men to use it in } \\
\text { adolescence. }\end{array}$ & $\begin{array}{l}\text { Rempong is a word } \\
\text { that is used by women } \\
\text { to call the men who are } \\
\text { women's to do activity } \\
\text { or dress. }\end{array}$ \\
\hline 2. & $\begin{array}{l}\text { Bohay is a word that } \\
\text { is used by men to } \\
\text { call sexy women. }\end{array}$ & $\begin{array}{l}\text { Cucok is a word for } \\
\text { men when he wears the } \\
\text { shirt like women. }\end{array}$ \\
\hline 3. & $\begin{array}{l}\text { Rebel is a word } \\
\text { which is enclosed } \\
\text { for men as his } \\
\text { bravery to do } \\
\text { extreme acting. }\end{array}$ & $\begin{array}{l}\text { Mahok is a word to call } \\
\text { men when two men are } \\
\text { like a couple of love. }\end{array}$ \\
\hline 4. & $\begin{array}{l}\text { Purel is a word for } \\
\text { the women who are } \\
\text { working in the } \\
\text { obscure cafe. This is } \\
\text { enabled for the } \\
\text { women 18-21 years } \\
\text { old. }\end{array}$ & $\begin{array}{l}\text { Jeng is a nickname for } \\
\text { women when they are } \\
\text { close friends. }\end{array}$ \\
\hline 5. & $\begin{array}{l}\text { Perex is a calling } \\
\text { name for the women } \\
\text { who are very } \\
\text { naughty when she is } \\
\text { with men. }\end{array}$ & $\begin{array}{l}\text { Shopping is a word for } \\
\text { men and women } \\
\text { actually. But the } \\
\text { women use more than } \\
\text { men. Because the } \\
\text { women are popular } \\
\text { with fashion. }\end{array}$ \\
\hline 6. & $\begin{array}{l}\text { Pinky is a word for } \\
\text { men who are rather } \\
\text { womanish. This case } \\
\text { is used when men } \\
\text { see another one } \\
\text { using something } \\
\text { pink. }\end{array}$ & $\begin{array}{l}\text { Tayang (sayang) is a } \\
\text { word that is used by } \\
\text { women for her } \\
\text { boyfriend. }\end{array}$ \\
\hline 7. & $\begin{array}{l}\text { Madesu is a word } \\
\text { that is used to call } \\
\text { the other men who } \\
\text { are jobless. It is } \\
\text { often used by men } \\
\text { than women. }\end{array}$ & $\begin{array}{l}\text { Sundel is a word that is } \\
\text { often used by women } \\
\text { to call the woman or } \\
\text { women who have } \\
\text { many styles in making } \\
\text { up and acting. It looks } \\
\text { like the high status of } \\
\text { social. }\end{array}$ \\
\hline 8. & $\begin{array}{l}\text { Bro is a nickname } \\
\text { for men. It is usually } \\
\text { used for the close } \\
\text { friend. }\end{array}$ & $\begin{array}{l}\text { Endel is a word for } \\
\text { women who are too } \\
\text { spoiled and over to } \\
\text { dress. }\end{array}$ \\
\hline 9. & $\begin{array}{l}\text { Bawel is a word that } \\
\text { is used by men to } \\
\text { call the women who } \\
\text { are fussy. }\end{array}$ & $\begin{array}{l}\text { Bronis is a word to call } \\
\text { the men who are } \\
\text { younger than the } \\
\text { women in a couple of } \\
\text { love. }\end{array}$ \\
\hline 10. & $\begin{array}{l}\text { One ball is words } \\
\text { that are used by men } \\
\text { to call the only } \\
\text { cigarettes in a pack. }\end{array}$ & $\begin{array}{l}\text { Dedek is a word to call } \\
\text { the baby that is used by } \\
\text { women. }\end{array}$ \\
\hline
\end{tabular}

An Analysis of Slang Language as Social Variation Produced by Men and Women's Speech in Lamongan 


\section{CONCLUSION}

The characteristics of language development to men and women's speech18-21 years old are actually supported by cognitive progress. The ability of men and women in language was affected by association with peering friends, television, internet and culture. The progress of adolescent language was completed and enriched by society where they stay. It was produced from association of society that formed language variation. It was enables for the effect of association between family and society in language development which differed the language as communication. This case brought about variation of words that are not standard. There were many language variation that happened in sentences, words and sounds that used for communication. It is different from language which was used by woman and man. They are tended to use it as the description of modern environment and high social status. Language as communication that was used by men and women's speech in age 18-21 years old was various. The variation happens not only in the sentence but also words and sound. It flows in the development of age. It is very modern and difficult to accept with the old. They usually used nonstandard vocabularies to communicate with the others. They felt that they had high social and looked like stylish in using language. So, the language they used was different from women and men.
Men and women's speech still used new variation vocabularies as communication in a group. The words that they used were difficult to understand as if they created the variation words by themselves. It can be from word to word which produces a new vocabulary, and it can be from the different culture that they stay. There is also the combination of language such as combination Indonesian and Javanese, Indonesian and English and Javanese and English. The men and women's speech used their language in variety. It usually can be understood by men and women in the group.

\section{REFERENCES}

Arikunto, Suharsimi. 2010. Prosedur Penelitian. Jakarta: Rineka Cipta

Bogdashima, Olga. 2005. Communication issues in Autism and Asperger Syndrom_ Do We Speak the same Language. London: Kingsley.

Coulmas, Forian. 1998. The Handbook of Sociolinguistics. United Kingdom: Blackwell

Ibrahim, Syukur, Abdul. 2009. Kemestaan Sosiolinguistik. $\quad$ Malang: Universitas Negeri Malang.

Meyer, Charles F. 2009. Introducing English Linguistics. New York: Cambridge University

Wardhaugh, Ronald. 2006. An Introduction of Sociolinguistic. United Kingdom: Blackwell. United Kingdom 